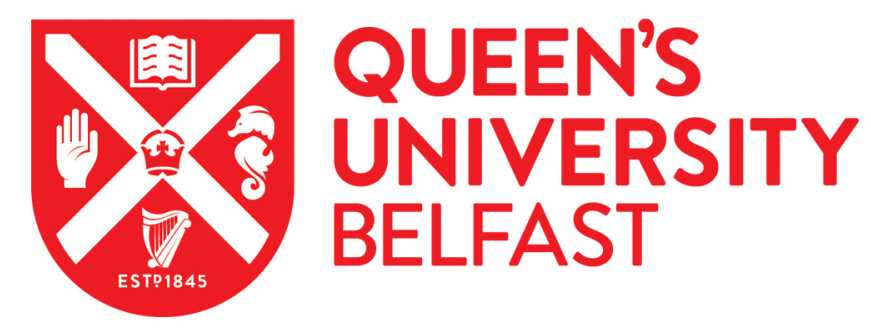

\title{
Exotic Endurance: Tourism, Fitness and the Marathon des Sables
}

Lisle, D. (2016). Exotic Endurance: Tourism, Fitness and the Marathon des Sables. Environment and Planning D: Society and Space, 34(2), 263-281. https://doi.org/10.1177/0263775815613094

Published in:

Environment and Planning D: Society and Space

Document Version:

Peer reviewed version

Queen's University Belfast - Research Portal:

Link to publication record in Queen's University Belfast Research Portal

Publisher rights

(C) 2015, The Author

\section{General rights}

Copyright for the publications made accessible via the Queen's University Belfast Research Portal is retained by the author(s) and / or other copyright owners and it is a condition of accessing these publications that users recognise and abide by the legal requirements associated with these rights.

Take down policy

The Research Portal is Queen's institutional repository that provides access to Queen's research output. Every effort has been made to ensure that content in the Research Portal does not infringe any person's rights, or applicable UK laws. If you discover content in the Research Portal that you believe breaches copyright or violates any law, please contact openaccess@qub.ac.uk. 
TITLE: Exotic Endurance: Tourism, Fitness and the Marathon des Sables

ABSTRACT: This paper critically examines the intersections of global tourism and fitness in the Marathon Des Sables (MdS), an annual ultramarathon in the Sahara desert in which over a thousand athletes run the equivalent of 5 marathons in 6 days. It demonstrates how the globalization of health and fitness resonates with familiar Western productions of exotic cultures for the purposes of tourist consumption. Of particular interest here is how established colonial asymmetries are recast in a Neoliberal context as runners test their resilience, endurance and strength against an 'extreme' Saharan landscape. While the paper calls attention to these asymmetries, it is more concerned with troubling reductive colonial encounters in order to reveal their instability, heterogeneity and ambivalence. Indeed, the central conceit of the MdS - that superior Western fitness regimes and technologies will dominate the race - is inverted by the overwhelming success of Moroccan runners and disaggregated by the biopolitical regulation of elite running bodies. These unexpected intersections of global tourism and fitness demand further attention because they reconfigure our received notions of who (and what) is capable of exerting agency in postcolonial encounters.

KEYWORDS: tourism, fitness, postcolonial, biopolitical, Neoliberalism, Marathon des Sables 


\section{The Toughest Race on Earth:}

Every April in the South-east corner of the Saharan desert in Morocco, over a thousand runners from around the world gather to participate in the Marathon Des Sables (MdS), a 6 day, $254 \mathrm{~km}$ ultramarathon that is publicized as 'the toughest footrace on earth' (Marathon des Sables / United Kingdom, 2015a). It is the equivalent of over five full marathons run sequentially, but runners must carry all their food and clothing on their backs and camp each night in the desert. Race organizers ensure that runners carry sufficient calories in their packs, are provided with adequate water supplies at numerous stages throughout the race (including salt tablets) and undergo medical evaluations at each check-point to ensure they can keep running. The MdS is one of the most established global endurance events with a large presence on social media, dedicated national websites, celebrity participation, a charity infrastructure, sponsorship by numerous multinational companies, and global media exposure. The race, which has just celebrated its $30^{\text {th }}$ anniversary, has become so popular that regular places are now fully-booked two years in advance.

I want to use the MdS as a starting place to explore what happens when dominant Western discourses of tourism and fitness converge in the Global South. For participants, organizers and their families, the MdS is undoubtedly a tourist experience facilitated by the Moroccan state and its well-established tourism industry. Indeed, part of my aim in this paper is to analyse how a tourist framing enables MdS visitors to reproduce a familiar colonial imagination in which strange, forbidding, and alien landscapes populated by exotic Others are imagined in advance in order to be conquered. But the MdS is also something else: it is the ultimate endurance race for individuals seeking to achieve the ideal Neoliberal body: healthy, fit, efficient, ascetic, resourceful, flexible and resilient. This paper critically 
examines how those desires for extreme fitness map onto the colonial asymmetries underscoring global tourism, and asks whether such an alignment offers possibilities for reordering global power relations. By inverting and disaggregating these asymmetries, my aim is to foreground the liveliness, complexity and ambivalence of cross-cultural encounters. So while the paper does call attention to the powerful colonial echoes within the MdS, it is more interested in the awkward, unexpected and unruly moments that rearrange the constitutive asymmetries of Empire.

A growing body of literature within Sociology and Public Health examines how a dominant discourse of Health - often called 'Healthism', or 'Healthification' - produces and governs modern Neoliberal subjects (Crawford, 1980; Fusco, 2006; King, 2013; Metzl \& Kirkland, 2010). Within this context, physical fitness - running, working out, taking exercise classes, focusing on diet and nutrition, playing competitive sports - develops powerful 'techniques of the self' through which subjects strive to achieve a resilient Neoliberal body capable of thriving in a highly competitive global marketplace (Andrews, Sudwell \& Sparkes, 2005; Dworkin \& Wachs, 2009; Millington, 2014; Rasmussen, 2011; White, Young \& Gillett, 1995). Focusing specifically on running, Geographers and Sociologists have traced the extent to which Neoliberalism has instrumentalized the positive feelings of empowerment derived from running so that fit subjects are rendered more productive subjects (Bridel, 2013; Hockey \& Allen-Collinson, 2006; Howe \& Morris, 2009; Latham, 2015; Lorimer, 2012; Tulle, 2007; Van Ingen, 2004). In combining these accounts of Neoliberal fitness with critical scholarship on global tourism (Bianchi \& Stephenson, 2014; Hall \& Tucker, 2004; d'Hauteserre, 2004), this paper calls attention to how discourses of fitness reproduce the colonial tendencies of Western tourism in the Global South, but it also demonstrates the 
many ways that fitness-tourism intersections lay bare the contested, negotiated and ambivalent character of all cross-cultural encounters in postcolonial space. To grasp the changing nature of these encounters within our current Neoliberal landscape, the paper turns to biopolitics in order to reveal the technological construction of many of the foundational categories sustaining the colonial imaginary (e.g. nature, biology). Methodologically, the paper focuses on how modern MdS races are represented by participants in online blogs, webpages, interviews, twitter feeds, books, social media posts, newspaper and magazine articles, public lectures, photographs and films. Particularly helpful to this analysis are the official MdS webpages that provide visual, narrative and statistical accounts of each annual race, as well as the largely narrative accounts by MdS participants posted on running blogs and social media sites.

The paper begins with a postcolonial critique of the overwhelmingly white, Western, male, elite bodies who travel to Morocco every year to test their fitness against a 'pure' and extreme desert landscape. It focuses initially on how MdS participants produce their own resilience by conquering a forbidding Saharan landscape, and infuse that resilience with virtue by providing charity for needy locals. While these critiques are compelling, too often they efface the agency of local communities, reduce Western subjects to monolithic symbols of imperialism, and fail to account for both the ambivalence of all cross-cultural encounters and the multiple agencies enrolled in these contact zones. With this in mind, the paper re-reads the MdS through the successful Moroccan runners who invert colonial asymmetries by refusing their pre-designated status as 'abject colonized', and through visiting runners whose pursuit of authenticity through physical pain reveals a much wider mode of biopolitical governance that seeks to produce, incentivize and manage ideal 
Neoliberal bodies. In making a case for research that simultaneously calls attention to the persistence of colonial power relations within Neoliberalism as well as pointing out the constant inversion and disaggregation of such asymmetries, this paper pries open - and holds open - a modest space within which we can begin to explore the multiple human and non-human assemblages currently constituting cross-cultural encounters.

\section{Here We Go Again: Conquering the Desert and Helping the Poor}

As a form of niche fitness tourism, the MdS exhibits all the difficulties that emerge when privileged Western bodies (i.e. runners, race organizers, families) travel to the Global South in the pursuit of leisure. In the case of Morocco, the state's deliberate use of tourism to spearhead development, increase GDP and further globalize its economy has not significantly transformed the country's reliance on colonial institutions and networks of patronage. Indeed, there is much to suggest that events like the MdS further entrench, rather than overcome, Morocco's legacies of colonialism (Cohen \& Jaidi, 2006; Coleman \& Crang, 2002; Edwards, 2005; Minca \& Borghi, 2009: 29-31; Mowforth \& Munt, 2008). Take, for example, how MdS participants invoke a familiar colonial imagination that distances the Sahara as variously exotic, mysterious, threatening, forbidding, wild, empty and inscrutable, all the while protecting their privileged vantage points (Cauvin Verner, 2007; Graulund, 2006). Many of these accounts remove indigenous inhabitants from the desert landscape by reproducing Terra Nullius - the legal practice of emptying foreign landscapes to enable conquest and possession (Banner, 2005; Fitzmaurice, 2007). The remaining 'empty' space is written over in ways that confirm the centrality of the adventurer's home civilization as 
compared to the difference (e.g. exoticism, danger, extremity) of his/her destination. One of the most prominent ways that MdS participants write over the Saharan desert is through essentialized categories of nature as uncontaminated, immutable and primordial. Thus, Morocco's harsh, threatening and unforgiving landscape is fetishized as 'the end of the earth' - 'a sun-scorched lunar landscape... where it was hot enough for rocks to explode' and where ultramarathoners can 'cross some of the most arduous terrain on the planet, battling sandstorms and scorching temperatures over 50”' (PR Newswire, 2015; Hicks, 2010).

Such a purified construction of nature is bolstered by equally purified notions of biology. Unlike some forms of colonial encounter in which indigenous knowledge is valued and then utilized in the service of conquest, the colonial imagination mobilized by MdS participants so comprehensively empties the Sahara that it largely ignores - indeed, cannot even see - the local bodies that have always existed and thrived in the desert landscape. There is no romanticized Moroccan native here, no noble savage whose traditional relationship with the land gives him 'better' and more detailed knowledge. Writing out indigenous bodies enables MdS runners to import their preferred Western training techniques, fitness regimes, modes of surveillance and consumer products (e.g. hats, sunglasses, sunscreen, backpacks, water bottles, GPS watches, lip balm, specialist shoes and energy bars) that will 'equip' them for the impending battle against nature (Andy K. 2010; irunfar, 2010; Marathon des Sables / United Kingdom 2015b; Mews, 2012; WAA Ultra Official, 2015). For example, MdS runners are intensely focused on how their bodies will cope with the multiple threats contained in the Sahara desert - the wind, sun, light, heat and diverse topography of the race route (e.g. mountains, sand dunes, outcrops, plains). Unsurprisingly, sand becomes an object of 
obsession, meticulous research and communal discussion for runners, mostly about how to keep it out of one's socks, shoes, eyes, ears, cameras and shorts. The more this struggle is articulated, the more runners can reassure themselves that the natural landscape they are battling is authentic. Central to participant accounts of the MdS, then, is a colonial imaginary in which the Sahara is produced as a testing ground of pure, ancient and primordial nature that can only be conquered by the superiority of Western expertise and technologies.

Of course, such an empty desert laboratory can never be completely cleansed of its 'exotic' signifiers; indeed, the MdS is attractive precisely because it takes place in the deserts of Morocco rather than the suburbs of Cleveland or the villages of Somerset. In this sense, the colonial imagination of the tourist encounter does include local bodies, but only in ways that do not disturb the 'master-of-all-I-survey' position of the visitors (Pratt, 1992: 201-228). In many MdS accounts, Moroccans are represented as pre-modern subjects who have never encountered the paraphernalia of 'civilized' modern life such as the latest fitness gear adorning the bodies of visiting runners. For example, UK celebrity Ben Fogle describes running past the local spectators who 'sit on their haunches watching, waiting, waiting, waiting for something to happen in their lives' (that 'something' presumably being an ultramarathon), and high-fiving the Bedouin children to whom we must resemble spacemen' (Fogle, 2004). Some runners avoid contact with local children 'for fear of catching infection. I'd just give them the thumbs up usually' (Rich, 2008). Because 'life' doesn't actually happen for locals until the runners enter the picture and make it happen, Moroccans are configured outside of modernity and civilization, either confused at its arrival 
(e.g. the waiting men) or innocently enthusiastic (e.g. the locals who wave, clap and cheer for the runners) (Rodale, 2011).

The mobilization of 'superior' Western expertise and technologies to conquer the threatening desert landscape is also expressed in the organization, governance and management of the event itself. While the outward facing image of the MdS is about elite runners competing to conquer a harsh desert landscape, its supporting infrastructure reveals how colonial asymmetries have been adopted, adapted and re-issued by Neoliberalism. A sporting event of this size can only operate with the support of various multinational sponsors, in this case the main sponsors (e.g. Sultan Tea); official suppliers (e.g. Jeep); local technical partners (e.g. race merchandising); media partners (e.g. TV5Monde); and Institutional Partners (e.g. Moroccan National Tourist Office) (Marathon des Sables, 2015a). Having just celebrated its $30^{\text {th }}$ year, the MdS - along with Morocco's surrounding tourist infrastructure - is now a central conduit through which global capital penetrates the Moroccan state and reorients it towards Neoliberal values. For example, the company that organizes the race - Atlantide Organization Internationale (AOI) - sits at the apex of a logistics infrastructure founded on Neoliberal management structures such as 'responsive' leadership and 'flexible' employment policies. The temporary seasonal employment, informal contracts and low wages central to these 'flexible' policies mean that AOI only employs local workers for the duration of the race (Neilson \& Rossiter, 2005). ${ }^{1}$

Like many Neoliberal enterprises, the MdS seeks to mitigate its reproduction of these 'regrettable' but 'unavoidable' structural inequalities by publicizing its commitment to charity. In 2010, AOI consolidated all its charity work into one overarching association - the Solidarité Marathon des Sables (Marathon des Sables, 2015b). Using some of the $£ 3650$ fee 
paid by each competitor, Solidarite helps to develop the area around Ouarzazate where the race takes place, and has funded a sport initiation academy for children and a welcome centre for women. The official aim of the Solidarité programme is to 'promote the teaching of fundamental and universal values through sport from the youngest age, raise awareness of hygiene and safety among mothers and provide literacy classes' (Marathon des Sables, 2015b). The logic of offsetting privilege through charity is also operative at the individual level as MdS participants justify the time, money and resources needed to train for and travel to this event by raising money for global charities, often with a focus on Africa and development.

Central to this charity framework is the mobilization of virtue to efface structural inequalities: AOI's 'flexible' employment policies are forgotten amidst the publicity of Solidarité's local development work, and the selfishness required to become an ultramarathoner is justified by raising money to help those in need. These powerful claims of benevolence, good will and generosity seek to foreclose any criticism that the MdS is yet another Western Imperial enterprise exploiting those in the Global South. To further enhance their virtue, organizers link the MdS into a wider apparatus of development in which European funding - facilitated by the Moroccan state - enables local empowerment, sustainability and economic growth in and around Ouarzazate. Mds runners enact similar foreclosures by framing their endeavours as selfless - how can one criticize the altruism of runners who perform the heroic and self-punishing act of running 5 desert marathons in 6 days to help those in need? It is precisely here, in the dovetailing of structural and individual commitments to charity, that a postcolonial critique of the MdS is most needed. As many critical scholars have argued, charity is absolutely central to Neoliberal modes of 
governmentality that efface pernicious forms of exclusion by mobilizing highly-moralized dispositions of benevolence (Bell, 2013; Kapoor, 2012; Littler, 2008; Magubane, 2008). What this work suggests is that ethical notions of giving reinforce the very hierarchies of power they are designed to alleviate. As Žižek (2008: 19) explains, while acts of charity may, in themselves, do some 'good' for those considered to be 'in need', it does not mean that such acts exist outside of entrenched power relations:

Charity is the humanitarian mask hiding the face of economic exploitation. In a superego blackmail of gigantic proportions, the developed countries 'help' the underdeveloped with aid, credits and so on, and thereby avoid the key issue, namely, their complicity in and co-responsibility for the miserable situation of the undeveloped.

The irony underscoring acts of charity is that they fulfil the needs of the giver rather than the needs of the recipient who remains utterly silent in his/her abjection. They can be nothing other than abject, for to express any kind of agency would rob the donor of their untainted feelings of magnanimity (i.e. they need, I give). So while the framework of charity does provide a space within which local subjects appear in the MdS story, it is a position constructed wholly on the terms of the donor to serve his/her identity as benevolent and virtuous.

As a starting point, then, postcolonial critiques of the MdS are indispensable because they illustrate how the intersecting discourses of tourism and fitness reproduce colonial asymmetries. Personal accounts of the race project essentialized formations of nature waiting to be conquered by superior Western bodies, expertise and technologies. Such an 
authentic and timeless landscape only permits the kind of Otherness that does not trouble the familiar hierarchy of privileged travellers and benighted locals (i.e. even when Others appear they are entirely abject). While it is necessary to demonstrate the persistence of this colonial imaginary, we also need to pay attention to how that frame flattens, reifies and makes singular the multiple bodies that are mapped onto the convergence of tourism and fitness in postcolonial landscapes. It is only by digging underneath such already-written positions that the lively and heterogeneous experiences of cross-cultural encounter can be critically interrogated.

\section{Resistive Bodies: Postcolonial Inversions and the Stubborn Hauntings of Local Life}

One of the most compelling ways to deconstruct colonial asymmetries is to point out cases where the multiple logics holding the colonial hierarchy in place are turned on their heads. Undeniably, the Moroccan runners' dominance of the MdS race exemplifies this kind of postcolonial inversion. While entering only a small number of competitors each year (an average of 15 in the past 6 years, compared with UK entries consistently over 300 ), Morocco has achieved unrivalled success in the MdS. The Ahansal brothers have dominated the race for the past 15 years: since 1997, older brother Lachan has won 10 MdS races while younger brother Mohamad has won 5 races (1998; 2008; 2009; 2010; 2013), coming second in 2012, third in 2014 and eleventh in 2015 (Madsen, 2010; Marathon des Sables, 2015d). In addition, their protégé Rachid El Morabity won the 2011, 2014 and 2015 races, and as Table 1 illustrates, Moroccan runners have been a dominant presence in the Top 20 of the last 6 MdS races, winning 5 of them outright: 
Table 1: Moroccan success in the MdS, 2010-2015 (Marathon des Sables, 2015d)

\begin{tabular}{|l|l|l|l|l|}
\hline Year & $\begin{array}{l}\text { Total } \\
\text { Finishers }\end{array}$ & $\begin{array}{l}\text { \# of Moroccans in Top 20 } \\
\text { Places }\end{array}$ & $\begin{array}{l}\text { Total } \\
\text { Moroccan } \\
\text { Finishers }\end{array}$ & $\begin{array}{l}\text { \% of total } \\
\text { Moroccan Finishers } \\
\text { in Top 20 Places }\end{array}$ \\
\hline 2010 & 923 & $3\left(1^{\text {st }}, 5^{\text {th }}, 14^{\text {th }}\right)$ & 15 & $20 \%$ \\
\hline 2011 & 805 & $6\left(1^{\text {st }}, 2^{\text {nd }}, 5^{\text {th }}, 6^{\text {th }}, 14^{\text {th }}, 18^{\text {th }}\right)$ & 14 & $43 \%$ \\
\hline 2012 & 795 & $\begin{array}{l}6\left(2^{\text {td }}, 3^{\text {rd }}, 12^{\text {th }}, 17^{\text {th }}, 18^{\text {th }}\right. \\
\left.19^{\text {th }}\right)\end{array}$ & 13 & $46 \%$ \\
\hline 2013 & 970 & $5\left(1^{\text {st }}, 5^{\text {th }}, 6^{\text {th }}, 8^{\text {th }}, 12^{\text {th }}\right)$ & 16 & $31 \%$ \\
\hline 2014 & 917 & $5\left(1^{\text {st }}, 3^{\text {rd }}, 7^{\text {th }}, 12^{\text {th }}, 19^{\text {th }}\right)$ & 9 & $56 \%$ \\
\hline 2015 & 1237 & $\begin{array}{l}6\left(1^{\text {st }}, 2^{\text {td }}, 3^{\text {rd }}, 4^{\text {th }}, 11^{\text {th }},\right. \\
\left.17^{\text {th }}\right)\end{array}$ & 22 & $27 \%$ \\
\hline Average & $\mathbf{9 4 1}$ & $\mathbf{5}$ & $\mathbf{1 5}$ & $\mathbf{3 7 \%}$ \\
\hline
\end{tabular}

For anyone familiar with the history of Moroccan middle and long-distance running, this success will not come as a surprise. Indeed, competitive running has been well established in Morocco since the mid-1970s, and has produced several world champions and Olympians including Saïd Aouita and Hicham el Guerrouj (Redis, 2009). But the irrefutable Moroccan success in the MdS is politically significant because it taps into a very complex set of relations between sporting success and Empire - especially with respect to Athletics and middle/long-distance running. In his analysis of Kenyan long-distance runners, John Bale demonstrates how upsetting postcolonial success is for Western audiences, experts and athletes, and how much energy is spent trying to explain away this colonial inversion. While early African success was negated as an exception to the norm (i.e. he is an aberrant 'African'), more frequent, wide-spread and prominent African success has prompted different strategies of naturalization, idealization and appropriation (Bale, 2001: 225-226; see also Bale, 2000; Bale \& Cronin, 2003). For example, in trying to explain the consistent success of East African long-distance runners, Western representations often idealize these 
athletes as modern day 'Noble Savages' whose efficient movements and unprecedented stamina arise from a more direct relationship with the natural landscape (Bale, 2001: 225227).

Similar contortions are at work when Western MdS runners try to make sense of their much more successful Moroccan competitors. For example, one Canadian runner struggling through the sand dunes described Mohamad Ahansal with a mixture of awe and veneration: 'I glanced behind me and Mohamed was gliding (that's the only word I can think of to describe it) closer. His feet barely touched the sand before they lifted again as he floated across the dunes. He runs up and down them without slowing. It is a sight to behold' (XSNRG, 2007). Although Ahansal is revered here, he is once again separated off from the majority of runners - in this case because his more 'natural' gait enables him to 'fly' across the sand dunes. Runners were also surprised by his 'strange' local customs of sucking on green tea leaves (rather than specially calibrated energy gels) and eating a mixture of nuts, raisins and dates (rather than 'maximum calorie' energy bars) (Powell, 2010). Here, it is Ahansal's more 'natural' diet that renders him exceptional. Ahansal, it seems, looms large in the imaginaries of other runners: sometimes elevated to mythical levels as an athlete with magical abilities, and sometimes naturalized as a 'Noble Savage' with secret knowledge of the native landscape, customs and food. In all cases, of course, he is differentiated from other MdS competitors so as to more easily excuse his undeniable success. In the 2010 race, Ahansal's accomplishments were simply too much to bear for British Olympian James Cracknell. During filming for the Discovery Channel's Toughest Race on Earth programme, Cracknell lost his temper and was 'furious with himself for letting the whippet-like winner, Mohamad Ahansal (5ft 8in, 9st 4lbs) beat him' (Cracknell, 2011; Pidd, 2010a). Ahansal's 
victory was the ultimate transgression of the colonial order: this small local tour guide triumphed over Cracknell's behemoth Olympian physique as well as the thousands of pounds worth of expensive fitness technology, training regimes and expertise at Cracknell's disposal.

What becomes clear reading Ahansal's own accounts of the MdS is that his approach to the race is exactly the same as all the other runners. For example, when asked about his mental preparations at the overnight bivouac sites, he explains: '[I think about] food, muscles, shoes, stages, kilometres, mountains or not, go slowly or fast. I think exactly about the time [I will run]... I had every checkpoint time calculated based on each 10k and the terrain and effort' (Hicks, 2013). There is nothing exceptional here, no exotic ceremonies or magical rituals that confirm Ahansal's 'natural' advantage: just the mundane habits that all elite runners perform when planning their tactics for a big race. Ahansal's achievements in the MdS are important not just because they constantly transgress the colonial frames that seek to contain him, but also because they generate such intense and elaborate efforts to efface, negate, naturalize, assimilate and idealize him in order to secure a pre-ordained hierarchy with Western tourist-athletes at the top. How shocking, then, that the irrefutable success of Moroccan runners in the MdS continually turns that hierarchy on its head: no colonial, neocolonial or Neoliberal rhetoric can explain away how a small number of supposedly abject postcolonial bodies have so comprehensively beat Western tourist-athletes at their own game. Moments like these are powerful because they cannot be effaced: they are a stubborn presence that will not be reduced to an anomaly or exoticized into an irrelevance. They demand attention precisely because they invert the entire apparatus of colonial superiority. 
A slightly different postcolonial inversion is the story of 39 year old Italian runner Mauro Prosperi who became lost in the desert during the 1994 race when a freak sandstorm blew away all trail markings. After wandering alone in the desert for 9 days and nearly dying, he was rescued by an 8 year old Tuareg girl whose female relatives fed him goat's milk, tended to his injuries and helped him to a nearby military base for further medical attention:

Prosperi's only hope for survival in the Sahara was to stumble across someone capable of rescuing him, and he did - that eight-year-old girl. The marathoning Italian policeman and the goat-herding child stood in the same barren patch of sand at the same moment. Both were human beings, sharing roughly the same physiognomy. Yet the little girl was thriving, while the marathon man was dying (Kamler, 2004: 145).

It is not hard to see how this inverts the colonial hierarchy underscoring the MdS: the runner becomes a depleted and abject figure indebted to a resilient and magnanimous community capable of surviving where he is not. But what is more revealing is how subsequent narrations of this story tried to 'correct' this inversion by deploying markers of gender and race. As ultramarathoners struggle to overcome the limitations of their own physical bodies (including the markers of gender and race), what emerges is a form of bare life that is actively chosen - a cultivation of asceticism that renders 'obvious' markers of identity much less powerful (Rasmussen, 2011: 163; see also Hanold, 2010). What makes the MdS important here is how it enables the pursuit of asceticism by displacing markers of gender and race onto local subjects. For example, while tabloid accounts reasserted Prosperi's heroic masculinity by focusing on his determination to survive ('I drank urine and bat blood!'), his rescuers were feminized through their practices of nurturing and caring and 
racialized through their 'exotic' Muslim customs. As Prosperi himself (2014) recounts: 'They wouldn't allow me into the tent because I was a man, but they put me on a carpet in the shade of their verandah.'

Despite the instinctive power of such postcolonial inversions, they still leave a reductive colonial hierarchy in-tact that limits more nuanced accounts of instability, multiplicity and ambivalence. One way to open up such logics is through performative accounts of tourism that examine the 'staged' encounter between tourists and tourist workers (Edensor, 2000; 2001; 2007; Haldrup \& Larsen, 2010; Minca, 2010; Minca \& Wagner, 2015). Because both visitors and workers are quite aware of the false 'frontstage' and 'backstage' structuring of the tourist experience, all subjects engage in complex performances of pretence, acknowledgement, desire, indifference and solidarity that re-order the reductive frames of 'host' and 'guest'. For Minca (2010: 91), tourist encounters always create a 'space for the unexpected', which, 'as a genuine and ambivalent product of the encounter between the tourist subject and the tourist worker, can never be eliminated or simply reduced to real imprisonment or full control'. Such a performative approach is particularly useful when examining the four overnight bivouac sites constructed at each stage along the MdS's 6 day race route where runners recover, rehydrate and prepare for another desert marathon the following day. These makeshift constructions constitute a temporary community in which visiting runners and local workers are in close proximity to one another. Unsurprisingly, participant accounts of the bivouac sites reproduce a familiar colonial hierarchy: at the top are predominantly Western runners who are cared for by a multinational team of medical practitioners (doctors, nurses, volunteers) in the middle, all of whom are supported by the bottom layer - a group of Tuareg, Berber and Bedouin labourers that AOI employ to manage 
these spaces. Participant accounts of the bivouac sites overwhelmingly focus on two interrelated practices: shared obsessions over how to repair their damaged bodies (especially their feet), and emotional celebrations of the intense friendships immediately forged between like-minded runners from around the world.

What most interests me is how these performances are both disturbed and unravelled by the infrastructure of care they rely on - an infrastructure that relies on the local knowledge and highly sophisticated skill-sets of local labourers (i.e. the bottom rung). According to the dominant tourist gaze, Tuareg, Berber and Bedouin people should be surrounded by camels, hookahs, carpets and other exotic objects that signify 'traditional Moroccan life' for Western visitors. Instead, these figures are surrounded by - and indeed, employed to operate - all the modern systems and technologies required to facilitate a global sporting event of this size: medical equipment, sleeping tents, portable toilets, water tanks, crowd barriers, sponsor publicity, support vehicles (ATVs, Jeeps and camels), generators and satellite internet connections (Marathon des Sables, 2015c). While the local workers themselves are largely unseen within participant accounts of the MdS, the effects of their labour, skills and expertise are everywhere. As one runner explained, 'it was as if a giant hand had picked up the entire camp every morning and gently re-deposited it in a different place every afternoon, such was its architectural consistency' (Charlie, 2014). Recalling Minca's argument, that 'giant hand' can never be effaced, even in the most solipsistic account of runners disinfecting their blisters alongside their multinational comrades. Indeed, the entire enterprise of the MdS is made possible by the energy, skill and dedication of this labour force - a powerful formation of Moroccan agency that haunts the entire race. As exemplary contact zones where the backstage infrastructure of labour and care continually infiltrates 
the preferred tourist gaze, these bivouac sites portray a more complex and fluid postcolonial inversion that foregrounds the heterogeneity and ambivalence of encounter rather than a strict asymmetry.

\section{Regulated Bodies: Fitness Lifestyles and Biopolitical Governance}

What, then, of the elite bodies running the MdS? Do they, in some way, participate in the re-ordering of colonial hierarchies even if they are not inclined to transgress the norms upholding their privilege? One way to reassess these elite bodies is by examining how Neoliberal forms of governance have rendered them vulnerable by compromising their foundational fantasies of 'pure' nature and biology. In focusing on the violent outworkings of biopolitical governance, we often forget that Foucault's claims about 'making life live' were also - crucially - about making life flourish (Foucault, 2009; 2010; Rabinow \& Rose, 2006). Vitality, for Foucault, requires attention not just to the statistical, demographic and informational registers that govern the 'basic biological features' of a population, but also the cultural, therapeutic and psychological registers that lend meaning, fullness and value to those lives deemed worth living. In Foucaudian terms, modern subjectivity requires that we take ourselves as objects to be worked on, trained and perfected not through disciplinary power (i.e. 'you must do this'), but rather through 'techniques of the self' that turn us into self-managing agents (i.e. 'I want to do this - it is good for me'). For Nikolas Rose (1999: ix), life in advanced Western democracies would be impossible without the 'biopolitical project of self-realization': the production of selves who are responsible for their own well-being, who 'live life as if making a project of themselves' (1998:157), and who self-regulate in ways 
that habituate them to governing aims (Cruikshank, 1993; Rabinow \& Rose, 2006). To craft this kind of subjectivity, individuals 'develop a 'style' of living that will maximize the worth of their existence to themselves' (Rose, 1998: 157). In other words, they develop a 'lifestyle' that is actively chosen to give structure, meaning and form to the more difficult work of becoming self-governing subjects in advanced, liberal-capitalist states (Chaney, 1996; Featherstone, 1987; Sobel, 1981).

Central to this mode of self-governance are the public health programmes and commercial opportunities encouraging modern subjects to become more healthy, fit and productive Neoliberal citizens (Fullagar, 2002; Fusco, 2006; Lupton, 1995; Nadesan, 2011: 93-137; Rasmussen, 2011). The healthification of society requires the production of sick bodies suffering from 'lifestyle' diseases (e.g. obesity, alcoholism, HIV) who then become the targets of explicit forms of intervention to make them healthy bodies (e.g. nutrition guidance; addiction programmes; family planning). But healthification also produces fit bodies as ideal subjects who take their physical selves as objects to be transformed and improved through self-discipline, motivation and comprehensive training regimes. As Rasmussen (2011: 138) explains, 'If the fit body must be ever vigilant in maintaining its integrity, then it is compelled to continually work on itself. Athletes must be addicted to their own autonomy, unable to stop the continual act of striving toward physical perfection.' For me, ultramarathons like the MdS are extreme responses to the powerful forces encouraging us to continually 'master' our bodies through fitness regimes, and in this sense, they provide stark illustrations of how subjects actually go about crafting productive, resilient Neoliberal selves. 
MdS runners discipline their bodies, in part, through a desire for authenticity amidst what they see as the superficiality, anonymity and meaninglessness of modern life (Barnes, 2009: 239). As Lupton (1995: 143) explains,

Fitness activities represent the attempt of individuals to find their 'true selves', to uncover the 'fit' and lean individual hiding beneath layers of flesh, to bring together the mind and the body, to cope with the seemingly chaotic nature of life in the late twentieth century by mastering the body.

Ultramarathoners experience the 'exciting significance' of authenticity when they push their bodies to the limit and feel physical pain: 'The legitimacy of surviving in a symbolic game with pain, death and bodily injury brings to light a radical truth for the subject' (Atkinson, 2008; Le Breton, 2000: 1). As an event that both tests and confirms the runner's capacity for extreme self-discipline, the MdS is a valuable opportunity for motivated competitors to pursue an idealized ascetic physiology that stands in opposition to the 'bloated' masses and moral relativity of modern life (Hanold, 2010).

The self-discipline, punishment and corporeal management required by ultramarathoning is achieved through a complex mind / body split in which the body becomes an object to be tested, observed, surveyed and trained. In effect, 'the body becomes the 'alter ego', an adversary that has more or less its own will, and is forced into submission so as to obtain a performance from it' (Le Breton, 2000: 5). This mind / body split requires the ability to simultaneously ignore and access actual physical pain in order to perform rational body surveillance; identifying, assessing and evaluating pain levels; making decisions about 
solutions to pain; and carrying out an immediate plan to manage, bear and hopefully alleviate pain. As MdS competitor Nick Saunders (2014) claims:

The MdS is entirely about mind/body management. They key is total awareness of your mind and body and the discipline to take control of any situation that may arise. If your feet hurt - deal with it. If you are tired - deal with it. If your mind is weak and fatigued, deal with it. Eat painkillers, drink some more water, have some jelly babies, turn up the volume on the IPod, stop whinging, run faster and NEVER STOP (see also Humphreys, 2009).

The race organizers $\mathrm{AOI}$ facilitate this corporeal hyper-management through their detailed regulations, for example, they require a medical certificate with resting ECG report and vaccination update before the race, and they verify, monitor and enforce salt intake, water consumption (between 10.5 and 12 litres per day) and caloric load (minimum $2000 \mathrm{k} / \mathrm{cal}$ per day) (Marathon des Sables, 2015e).

Although these aspirations to the 'barest' form of ascetic life rely on essentialized accounts of biology, the bodies of ultramarathoners are actually complex bio-technical assemblages in which corporeal limits are continually breached (Rasmussen, 2011: 162-63). Cultivating asceticism relies not only on specially designed technologies (e.g. blister-proof socks, sandproof gaiters, GPS watches, sun hats, heat-resistant shoes, light-weight packs, electrolytebalancing energy gels), but also on a wide range of expertise provided by fitness instructors, physiotherapists, personal trainers, sports psychologists, life coaches, nutritionists and medics (Binkley, 2007: 119; Miller \& Rose, 1997; Peak Performance, 2014). The companies 
that produce fitness gadgets and offer expert advice are heavily invested in endurance races like the MdS because runners can be used as guinea pigs for new products, designs, technologies, training regimes, motivational strategies, recovery techniques and innovations aimed at enabling bodies to operate at maximum fitness levels in the harshest conditions. In the 2010 MdS, for example, British Olympian James Cracknell willingly 'surrendered his body to science, becoming a living, breathing, competing experiment' for the international defence technology company QinetiQ (Cracknell, 2011; Pidd, 2010b). A team of experts in sports science, biomechanics, physiology, nutrition and technology assessed the data provided by both the 'Life Monitor' system worn by Cracknell (which measured heart rate and skin temperature) and the radio pill he swallowed (which acted as an internal thermometer), and they manually monitored his hydration, weight and psychological state before and after each race stage (Pidd, 2010a).

Cracknell's story neatly expresses Foucault's claim that biopolitical governance doesn't just produce docile bodies utterly disciplined by invasive techniques of governance: it also produces highly active, motivated and willing bodies who, by offering themselves as laboratories and sites of intervention, enthusiastically participate in their own subjectification. They do this, in part, because it brings pleasure: ultramarathoners enjoy the process of objectifying their bodies, gleaning more detailed and precise information from it, and employing sophisticated medical, nutritional and sports science expertise to help them push their bodies even further (Le Breton, 2000: 5; Rasmussen, 2011: 161-62). The detailed stories of pain and suffering recounted by MdS runners comprehensively express the pleasure they derive from objectifying their own bodies: there are endless tales of non-stop 
vomiting and diarrhoea; uncontrollable sobbing due to foot blisters; adrenaline-induced insomnia and hallucinations; repeated bouts of cramping, dehydration, sunstroke, heat exhaustion, delirium and diarrhoea; and many other ailments as runners 'stumble, burn, stink, hallucinate, cry and bleed across 155 miles of the Sahara Desert' (Allyn, 2010; Bailey, 2010; Cunliffe, 2010; Finnegan, 2011; Hamlett, 2011). This biological authenticity-throughpain is meant to disavow the necessary technologies and expertise constantly being enrolled in the construction of the ultramarathoner's body. Indeed, these bodies are not 'bare' in any sense at all: they are technologically enhanced cyborgs.

What interests me about these multiply enhanced bodies is how they function as idealized subjectivities embodying the perfect Neoliberal skill-set. Here, the self-denial, self-discipline and self-regulation required to become an ultramarathoner are increasingly framed as 'entrepreneurial'. As 'problem solving, brain stretching, heart pumping experiences [that] cultivate self-awareness' (Horscroft, 2008), the MdS 'requires exactly the same skills required to succeed in business: vision, focus, discipline, determination to succeed and the persistence required to deliver outstanding results' (McMenemy, 2015; see also Barnes, 2009: 239). This entrepreneurial skill-set includes continual risk-assessment, complex problem solving, rapid decision making, stress-management, demonstration of agility and constant troubleshooting - characteristics that translate across public, professional and personal domains. Unsurprisingly, this convergence of ultramarathoning, entrepreneurialism and global business has spawned a niche industry of motivational speakers, life coaches and personal trainers who frame their experience running the MdS through the expert languages of sports psychology, self-help and management speak. This is 
a lucrative enterprise: global multinationals such as Ernst \& Young, Mars, Microsoft, IBM, Toyota, and American Express have all hired MdS runners to inspire and motivate their employees (Ewan, 2008; Guller, 2011; Humphreys, 2009).

Entrepreneurialism is a technique of biopolitical governance that disaggregates individual bodies and incentivizes them through Neoliberal structures of power, but these structures also order collective life, manage interpersonal relations and stipulate which modes of solidarity are permissible and which are not. In this sense, the MdS is never just a personal test of endurance: it is also a shared experience of hardship in which MdS runners 'come together as a mutually recognized 'pain community' of like-minded actors' (Atkinson 2008: 165). Indeed, although the MdS is an individual race, there is an increasingly prominent team component that attracts global sponsorship for elite competitors and helps amateur runners increase donations for charities. MdS participants recount numerous examples of collective support, community building and teamwork such as sharing food, water and clothing, helping repair blisters, providing massages, and most importantly, supporting each other during the difficult parts of the race. For example, Nicola Boyd's account of her 2012 MdS race is full of stories of runners supporting her throughout the 6 days by giving her food, water and medical attention. After a companion gave her one of his valuable energy gels on the last day of the race, she explained: 
That was a typical example of the type of camaraderie I experienced all week...One British guy even offered to carry extra water for me for one day! Everyone is in pain and suffering at one point or another and you help each other out, with verbal encouragement or as I had experienced on the long day - through companionship in running (Boyd, 2012)

Even more than the MdS, amateur adventure races - team-based, multiple activity endurance events such as Tough Mudder - are especially good examples of how fitness inculcates the specific Neoliberal skill of teamwork. Discussing the rise of adventure racing in the 1990s, Barbara Barnes (2009: 239) explains:

Adventure sports produced an enticing platform for making the specific kind of self-sufficient, risk-managing bodies and selves the neoliberal political, economic and cultural formations of the late $20^{\text {th }} \mathrm{C}$ required. With its constantly shifting environments, requirements for flexibility, personal endurance, and team self-sufficiency, adventure racing seemed a perfect training ground for these kinds of bodies and selves. Indeed, adventure racing is often spoken of as a metaphor for life and as good training for the requirements of civic belonging (see also Atkinson, 2008).

Fitter bodies are more 'civic-minded' bodies: more efficient, more productive, and more engaged. The self-discipline, self-motivation and - above all - self-governance, necessary to succeed in both individual and team-based endurance events are also necessary to succeed in a global Neoliberal economy that is characterized by ruthless competition, a consumer culture that breeds alienation and discourages civic engagement, a career trajectory that 
demands rigorous focus and instrumental planning, and a web of family and community relationships that requires constant emotional attention. The future reward for those fit enough to embody Neoliberalism's ideal entrepreneurial skill-set and commitment to teamwork is heroic status. As Barnes (2009: 239) goes on to explain, endurance events like ultramarathons 'may serve to establish the kinds of fit, agile and courageous bodies the nation is seen to need at a moment when so many aspects of social life - including work, identity, community, national borders, and transnational threats - are likewise perceived to be flexible and insecure'.

While exploring the pernicious convergence of Neoliberalism and biopolitical governance is important, it does not adequately differentiate between the techniques of subjectification at work on elite bodies and those at work on postcolonial bodies. There is no doubt that the bodies of MdS runners are subject to multiple modes of biopolitical governance: they are disciplined, managed and incentivized in ways that can reduce the quality and capacity of their agency. But are those conditions really comparable to the multiple and often violent modes of biopolitical intervention enacted upon precarious bodies in the Global South? One of the difficulties of deploying biopolitics is that techniques of control have become so deterritorialized that it is impossible to distinguish between genuinely 'bare' life stripped of all agency (if that is even possible) and other lives that are ordered, managed and controlled in less violent ways (Dauphinée \& Masters, 2007; Debrix \& Barder, 2009; Larner \& Walters, 2004; Ong, 2006; Ticineto Clough \& Willse, 2011). With this in mind, Sharma (2008: 139) has called for a 'differential theory of biopolitics' to investigate how the 'biopolitical infrastructure that upholds the lifestyle of the overly invested is built upon the labour and 
bodies of the disinvested'. As she goes on to say: 'The biopolitical regulation of life reduces certain life to bare life. At the same time it also invests in the lives of others, as in the maintenance of lifestyles' (Sharma, 2008: 139). Certainly Sharma's argument provides much needed perspective on this initial account of how the elite bodies running the MdS are subject to biopolitical governance, but much more work is needed to attach that mode of governance to a global apparatus of power that includes the labour and bodies of the disinvested'.

\section{Crafting Relationality: intersections of resistive and regulated bodies}

I see this paper very much as a starting point - a preparatory effort that enables us to better understand the multiple entanglements of tourism, fitness and colonial asymmetries. I use the example of the MdS to demonstrate two important critical moves. Firstly, I show how colonial asymmetries continue to be reproduced when discourses of tourism and fitness intersect in the Global South. In a rather depressing echo of their $19^{\text {th }}$ Century forbearers, MdS participants construct local landscapes as exotic, threatening, and ready to be conquered, and when local subjects do appear in the dominant imaginary at all, they are either quaintly pre-modern or dutifully abject. Secondly, I trouble that ordering by foregrounding the agency of postcolonial bodies that invert entrenched narratives of subordination, and demonstrating how the agency of elite bodies is compromised by pernicious forms of biopolitical regulation. These efforts to complicate MdS encounters produce a rather uncomfortable set of responses; feelings of joy that a small number of Moroccan endurance runners continue to defeat the most over-invested, hyper-equipped and highly trained ultramarathoners year after year, and feelings of despair that even the 
most privileged bodies are subject to techniques of governance that reduce their agency and freedom. By deconstructing and re-ordering a reductive colonizer/colonized logic, the paper sets up a position from which to think about resistive and regulated bodies together in ways that do not efface or flatten their constitutive asymmetries.

Pushing that kind of analysis even further with respect to the MdS, it would be useful to explore how the race - and other events like it - intersects with wider structures of global power. For example, how does the biopolitical governance of health and fitness so central to the subjectivity of ultramarathoners map onto the governance of local bodies through large-scale regional and national development projects? What kinds of subjects are being produced by Solidarité's sports academy and women's centre, and do these differ from the kinds of subjects being produced by NGO, charity, religious and state-funded development projects in Southern Morocco? More to the point, how are Neoliberal values being inculcated through these various practices of development? Another possibility to explore is how the race route of the MdS becomes part of the global security apparatus currently trying to stop violent conflict in Mali and Niger and stem the flow of irregular migrants heading north to the enclaves of Ceuta and Melilla. Do migrant routes pass through Ouzarzate? If so, how do local communities and state structures manage these flows, and how are those efforts balanced with their facilitation of the MdS? Has the MdS ever been a target? Or a security risk? These brief suggestions continue in the vein of this paper by showing why it is not enough to simply stop after a postcolonial critique because even the most obvious rendering of a colonizer/colonized logic (even an inverted one) contains contingency, instability and ambivalence. For me, the challenge is to develop more nuanced, 
adaptive and detailed accounts of power that do justice to heterogeneity without losing sight of the historical asymmetries that always attend cross-cultural encounters. So while an initial response to the MdS may be a mixture of incredulity and anger (e.g. "What are these Western, masculine, privileged bodies doing running across the desert?'), such reactions can only ever be a starting place to explore the multiple and often unexpected expressions of agency that circulate through such an event.

\section{References:}

Allyn, Matt (2010) 'Inner Workings: Marathon des Sables' Runner's World, July, available at http://www.runnersworld.com/article/0,7120,s6-239-582--13544-0,00.html, [accessed 14/01/15].

Andrews, Gavin J.; Sudwell, Mark I. \& Sparkes, Andrew C. (2005) 'Towards a Geography of Fitness: an ethnographic case study of the gym in British body building culture', Social Science and Medicine, 60:4, 877-891.

Andy K. (2010) 'Kit and tips for the Marathon des Sables', A Reluctant Runner, available at http://reluctant-runner-2009.blogspot.com/p/kit-and-tips-for-marathon-dessables.html, [accessed 23/01/15]

Atkinson, Michael (2008) 'Triathlon, Suffering and Exciting Significance' Leisure Studies, 27(2): 165-180. 
Bailey, Ryan (2010) 'Inspirational Men: Charlie Pitcher' Men's Health, available at http://www.menshealth.co.uk/living/men/imhi-inspirational-men-transatlanticrower-charlie-pitcher-405843 [accessed 14/01/15]

Bale, John (2001) 'Nyandika Maiyoro and Kipchoge Keino: transgression, colonial rhetoric and the postcolonial athlete' pp. 218-230 in David L. Andrews \& Steven J. Jackson, eds. Sport Stars: The Cultural Politics of Sporting Celebrity. London: Routledge.

Bale, John (2000) 'Sport as Power: Running as Resistance?', pp. 148-163 in Joanne P. Sharp, Paul Routledge, Chris Philo \& Ronan Paddison, eds., Entanglements of Power: Geographies of Domination / Resistance. London: Routledge.

Bale, John \& Cronin, Mike, eds. (2003) Sport and Postcolonialism. Oxford: Berg.

Banner, Stuart (2005) 'Why Terra Nullius? Anthropology and Property Law in Early Australia' Law and History Review, 23:1, 95-131.

Barnes, Barbara A. (2009)'Everybody Wants to Pioneer Something out Here': Landscape, Adventure, and Biopolitics in the American Southwest', Journal of Sport and Social Issues, 33:3, 230-256.

Bell, Katherine M. (2013) 'Raising Africa? Celebrity and the Rhetoric of the White Saviour', Portal: Journal of Multidisciplinary International Studies, 10:1, 1-24.

Bianchi, Raoul V. \& Stephenson, Marcus L. (2014) Tourism and Citizenship: Rights, Freedoms and Responsibilities in the Global Order. London: Routledge.

Binkley, Sam (2007) ‘Governmentality and Lifestyle Studies’, Sociology Compass, 1:1, 111126. 
Boyd, Nicola (2012) 'A Little Run in the Sahara', Marathon des Sables / United Kingdom, available at http://www.marathondessables.co.uk/site/news-article/nicola-boyd$\underline{2012}$ [accessed 15/05/15]

Bridel, William (2013) 'Not Fat, Not Skinny, Functional Enough to Finish: interrogating constructions of health in the Ironman Triathlon', Leisure/Loisir, 37(1): 37-56.

Cauvin Verner, Corinne (2007) Au Désert: Une anthropologie du tourism dans le Sud Marocain. Paris: L'Harmattan.

Chaney, David (1996) Lifestyles. London: Routledge.

Charlie (2014) 'Marathon des Sables Race Report - May 2014', Epic Morocco, 18 May, available at http://www.epicmorocco.co.uk/2014/05/marathon-des-sables-racereport-may-2014/ [accessed 15/05/15]

Cohen, Shana \& Jaidi, Larabi (2006) Morocco: Globalization and its Consequences. London: Routledge.

Coleman, Simon \& Crang, Mike, eds. (2002) Tourism: Between Place and Performance. London: Berghahn Books.

Cracknell, James (2011) 'Toughest Race on Earth with James Cracknell', James Cracknell, available at http://www.jamescracknell.com/news/2011/03/21/toughest race on earth with $\mathrm{i}$ ames cracknell-203?page=2 [accessed 23/01/15].

Crawford, Robert (1980) 'Healthism and the Medicalization of Everyday Life', International Journal of Health Services: planning, administration, evaluation, 10:3, 365-88. 
Cruikshank, Barbara (1993) 'Revolutions from within: self-government and self-esteem', Economy and Society, 22:3, 327-344.

Cunliffe, Steve (2010) 'Moroccan Madness', Men's Health, July, available at http://www.stevecunliffe.com/wp-content/uploads/2010/07/Mens-Health-SAMoroccan-Madness.pdf [accessed 14/01/15].

Dauphinée, Elizabeth \& Masters, Christina, eds. The Logics of Biopower and the War on Terror: Living, Dying, Surviving. New York: Palgrave MacMillan.

Debrix, Francois \& Barder, Alexander D. (2009) 'Nothing to Fear but Fear: Governmentality and the Biopolitical Production of Terror', International Political Sociology, 3:4, 398413.

Dworkin, Shari L. \& Wachs, Faye (2009) Body Panic: Gender, Health and the Selling of Fitness. New York: New York University Press.

Edensor, Tim (2007) 'Mundane Mobilities, performances and spaces of tourism', Social and Cultural Geography, 8:2, 199-215.

Edensor, Tim (2001) 'Performing tourism, staging tourism: (re)producing tourist space and practice', Tourist Studies, 1:1, 59-81.

Edensor, Tim (2000) 'Staging Tourism: tourists as performers', Annals of Tourism Research, $27: 2,322-344$.

Edwards, Brian T. (2005) Morocco Bound: Disorienting America's Maghreb, from Casablanca to the Marrakech Express. Durham: Duke University Press. 
Ewan, J. (2008) Sand in my Supper: Life Lessons from the Toughest Footrace on Earth. London: On Target Books.

Featherstone, Mike (1987) 'Lifestyle and Consumer Culture', Theory, Culture \& Society, 4:1, 55-70.

Finnegan, J. (2011) 'Marathon des Sables: the full account', finndesertmarathon, available at http://finndesertmarathon.blogspot.com/ [accessed 14/01/15].

Fitzmaurice, Andrew (2007) 'A Genealogy of Terra Nullius' Australian Historical Studies, 38:129, 1-15.

Fogle, Ben (2004) 'Sandstorms, Sunburn and Sore Feet', The Telegraph, $26^{\text {th }}$ April.

Foucault, Michel (2010) The Birth of Bio-Politics: Lectures at the College de France, Trans. Graham Burchill. Houndmills: Palgrave Macmillan.

Foucault, Michel (2009) Security, Territory, Population: Lectures at the College de France, Trans. Graham Burchill. Houndmills: Palgrave MacMillan.

Fullagar, Simone (2002) 'Governing the Healthy Body: Discourses of Health and Lifestyle within Australian Health Policy', Health, 6:1, 69-84

Fusco, Caroline (2006) 'Inscribing Healthification: governance, risk, surveillance and the subjects and spaces of fitness and health', Health and Place, 12:1, 65-78.

Graulund, Rune, (2006) 'Travelling the Desert: Desert Travel Writing as Indicator Species' Studies in Travel Writing, 10:2, 141-59. 
Guller, Gary (2011) 'Inspirational Keynote Speaker', Public Speaking Training, Executive Retreats, available on http://garyguller.blogspot.com/ [accessed 23/01/15].

Haldrup, Michael \& Larsen, Jonas, eds. (2010) Tourism, Performance and the Everyday: Consuming the Orient. London: Routledge.

Hall, C. Michael \& Tucker, Hazel, eds. (2004) Tourism and Postcolonialism: Contested Discourses, Identities and Representations. London: Routledge. \#

Hamlett, Alison (2011) 'Desert Storm: Taking on the Marathon des Sables' Runner's World, available at http://www.runnersworld.co.uk/event-editorial/desert-storm-taking-onthe-marathon-des-sables/6991.html [accessed 14/01/15].

Hanold, Maylon (2010) ‘Beyond the Marathon: (De)constructing Female Ultrarunning Bodies', Sociology of Sport Journal, 27(2): 160-177.

d'Hauteserre, Anne Marie (2004) 'Postcolonialism, Colonialism and Tourism', pp. 235-245 in Alan A. Lew, C. Michael Hall \& Allan M. Williams, eds. A Companion to Tourism. Oxford: Wiley.

Hicks, Meghan (2013) 'Mohamad Ahansal, 2013 Marathon des Sables Champion, Interview', irunfar, 17 April, available at http://www.irunfar.com/2013/04/mohamad-ahansal2013-marathon-des-sables-champion-interview.html [accessed 15/05/15]

Hicks, Meghan (2010) 'Indurare: the 2010 Marathon des Sables'. Meghan M. Hicks, available at http://www.meghanmhicks.com/2010/05/15/indurare-the-2010-marathon-dessables/ [accessed 21 January 2015]. 
Hockey, John \& Allen-Collinson, Jacquelyn (2006) 'Seeing the Way: visual sociology and the distance runner's perspective', Visual Studies, 21(1), 70-81.

Horscroft, John (2008) 'Risk's Grand Arena' Planet Fear, available at http://www.planetfear.com/articles/Risks Grand Arena 1029.html [accessed $14 / 01 / 15]$

Howe, Davis \& Morris, Carol (2009) 'An Exploration of the Co-Production of Performance Running Bodies and Natures Within 'Running Taskscapes", Sport and Social Issues, 33:3, 308-330.

Humphreys, Alistair (2009) 'Marathon des Sables', Alistair Humphreys, available at http://www.alastairhumphreys.com/adventures/mds/ [accessed 17/01/15].

Irunfar (2010) ‘Marathon des Sables Gear/Kit List', irunfar.com, available at http://www.irunfar.com/2010/03/marathon-des-sables-gearkit-list.html [accessed 23/01/15]

Kamler, Kenneth (20040 Surviving the Extremes: A Doctor's Journey to the Limits of Human Endurance. New York: Penguin Books.

Kapoor, Ilan (2012) Celebrity Humanitarianism: The Ideology of Global Charity. London: Routledge.

King, Samantha (2013) 'Philanthrocapitalism and the Healthification of Everything', International Political Sociology, 7:1, 96-98.

Larner, Wendy \& Walters, William, eds. (2004) Global Governmentality: Governing International Spaces. London: Routledge. 
Latham, Alan (2015) 'The History of a Habit: jogging as a palliative to sedentariness in 1960s America', Cultural Geographies, 22:1, 103-126.

Le Breton, David (2000) 'Playing Symbolically with Death in Extreme Sports', Body and Society, 6:1, 1-11.

Littler, Joe (2008) 'I Feel Your Pain’: Cosmopolitan Charity and the Public Fashioning of the Celebrity Soul', Social Semiotics, 18:2, 237-251.

Lorimer, Hayden (2012) 'Surfaces and Slopes', Performance Research: A Journal of the Performing Arts, 17:2, 83-86.

Lupton, Deborah (1995) The Imperative of Health: Public Health and the Regulated Body. London: Sage.

MacCannell, Dean (1999) The Tourist: a New Theory of the Leisure Class. Berkeley: University of California Press.

Madsen, Christian (2010) 'The Sandman', Ultrarun, 2010, available at http://ultrarun.com/en/2010/06/manden-fra-\%C3\%B8rkenen/ [accessed 15/01/15]

Magubane, Zine (2008) 'The (Product) Red Man's Burden: Charity, Celebrity, and the Contradictions of Coevalness', Journal of Pan African Studies, 2:6, 1-25.

Marathon des Sables (2015a) ' $30^{\text {th }}$ Sultan MDS Edition 2015: Partners', available at http://www.marathondessables.com/MDS-official/en/partners/main-sponsor.html\# [accessed 03/05/15] 
Marathon des Sables (2015b) ' $30^{\text {th }}$ Sultan MDS Edition 2015: Solidarite - Marathon des Sables', available at http://www.marathondessables.com/MDS-official/en/themds/solidarity.html\# [accessed 03/05/15]

Marathon des Sables (2015c) ' $30^{\text {th }}$ Sultan MDS Edition 2015: Figures', available at http://www.marathondessables.com/MDS-official/en/the-mds/figures.html\# [accessed 03/05/15]

Marathon des Sables (2015d) ' $30^{\text {th }}$ Sultan MDS Edition 2015: Archives', available at http://www.marathondessables.com/MDS-official/en/ [accessed 03/05/15]

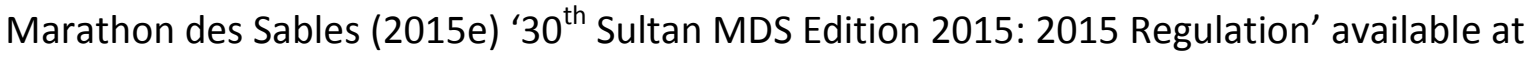
http://www.marathondessables.com/MDS-official/en/the-mds/regulation2015.html\# [accessed 04/05/15]

Marathon des Sables / United Kingdom (2015a) 'The Toughest Footrace on Earth', available at http://www.marathondessables.co.uk/ [accessed 16/04/15]

Marathon des Sables / United Kingdom (2015b) 'Important Info', available at http://www.marathondessables.co.uk/site/content/important-info [accessed 03/05/15]

McMenemy, Andy (2015) Andy McMenemy, Flickr, https://www.flickr.com/people/desertrunner/ [accessed 04/05/15].

Metzl, Jonathan \& Kirkland, Anna, eds. (2010), Against Health: How Health Became the New Morality. New York: New York University Press. 
Mews, Tobias (2012) 'Ten ways to survive the Marathon des Sables', runnersworld.co.uk, available at http://www.runnersworld.co.uk/event-editorial/10-ways-to-survive-themarathon-des-sables/6994.html, [accessed 23/01/15]

Miller, Peter \& Rose, Nikolas Rose (1997) 'Mobilizing the Consumer: Assembling the Subject of Consumption', Theory, Culture and Society, 14:1, 1-36.

Millington, Brad (2014) 'Amusing Ourselves to Life: Fitness, Consumerism and the Birth of Bio-Games', Journal of Sport and Social Issues, 38:6, 491-508.

Minca, Claudio (2010) 'The Island: Work, Tourism and the Biopolitical', Tourist Studies, 9:2, 88-108.

Minca, Claudio (2007) 'The Tourist Landscape Paradox', Social and Cultural Geography, 8:3, 433-453.

Minca, Claudio \& Borghi, Rachele (2009) 'Morocco: Restaging Colonialism for the Masses', pp. 21-52 in Pau Obrador Pons, Mike Crang \& Penny Travlou, eds. Cultures of Mass Tourism: Doing the Mediterranean. Aldershot: Ashgate.

Minca, Claudio \& Wagner, Lauren (2015) Moroccan Dreams: Recreating Oriental Myth and Colonial Legacy. London: I.B. Taurus.

Mowforth, Martin \& Munt, Ian (2008) Tourism and Sustainability: Development, Globalization and New Tourism in the Third World, $3^{\text {rd }}$ ed. London: Routledge.

Nadesan, Majia Holmer (2011) Governmentality, Biopower and Everyday Life. London: Routledge. 
Neilson, Brett \& Rossiter, Ned (2005) 'From Precarity to Precariousness and Back Again: Labour, Life and Unstable Networks', The Fibreculture Journal, 5: FCJ-022, available at http://five.fibreculturejournal.org/fcj-022-from-precarity-to-precariousness-andback-again-labour-life-and-unstable-networks/ [accessed 15/05/15]

Ong, Aihwa (2006) Neoliberalism as Exception: Mutations in Citizenship and Sovereignty. Durham: Duke University Press.

Peak Performance (2014), 'Sports Psychology: Endurance Training', Peak Performance, available at http://www.pponline.co.uk/encyc/sports-psychology-endurance-training [accessed 14/01/15].

Peterson, Alan \& Bunton, Robin, eds. (1997) Foucault, Health and Medicine. London: Routledge.

Pidd, Helen (2010a) 'James Cracknell runs for the wire in the Marathon des Sables, The Guardian, $6^{\text {th }}$ April, available at http://www.guardian.co.uk/sport/2010/apr/06/cracknell-marathon-science, [accessed 23/01/15]

Pidd, Helen (2010b) 'Olympian works to the bone for ultramarathon', The Age, $7^{\text {th }}$ April, available at http://www.theage.com.au/world/olympian-works-to-the-bone-forultramarathon-20100406-rpcw.html [accessed 23/01/15].

Powell, Bryon (2010) 'Mohamad Ahansal (Marathon des Sables Champ) Video Interview, irunfar, $12^{\text {th }}$ April, available at http://www.irunfar.com/2010/04/mohamad-ahansalmarathon-des-sables-champ-video-interview.html [accessed 10/01/15]. 
Pratt, Mary Louise (1992) Imperial Eyes: Travel Writing and Transculturation. London: Routledge.

Prosperi, Mauro (2014) 'How I drank urine and bat blood to survive', BBC News Magazine, $27^{\text {th }}$ November, available at http://www.bbc.co.uk/news/magazine-30046426 [accessed 27/04/15]

PR Newswire (2015) 'On-Line for the Marathon des Sables in the Sahara', available at http://www.prnewswire.co.uk/cgi/news/release?id=30676 [accessed 10/01/15]

Rabinow, Paul \& Rose, Nikolas Rose (2006) 'Biopower Today', Biosocieties, 1:2, 195-217.

Rasmussen, Claire E. (2011) The Autonomous Animal: Self-Governance and the Modern Subject. Minneapolis: University of Minnesota Press.

Redis, Courtenay Morgan (2009) 'At Home with Abderrahim Goumri' Running Times, December 2009, available at http://runningtimes.com/Article.aspx?ArticlelD=17884\&PageNum=2 [accessed $10 / 01 / 15]$

Rich (2008) 'Marathon des Sables 2008 - My Story', available at http://mds2008.blogspot.com/2008/04/marathon-des-sables-2008-my-story.html [accessed 20/01/15].

Rodale, Anthony (2011) 'Marathon des Sables: Rolling the Dice in the Desert' Runners' World, $29^{\text {th }}$ March, available at http://www.runnersworld.com/runnersstories/marathon-des-sables-rolling-dice-desert [accessed 21/01/15]. 
Rose, Nikolas (1999) Governing the Soul: The Shaping of the Private Self, $2^{\text {nd }}$ ed. London: Free Association Books.

Rose, Nikolas (1998) Inventing Ourselves: Psychology, Power and Personhood. Cambridge: Cambridge University Press.

Saunders, Nick (2014) 'Marathon des Sables 2014', Richmond Park Academy, 4 June, available at https://sites.google.com/a/aetinet.org/richmond-park-academywebsite/news/academy-news/marathondessables2014 [accessed 15/05/15]

Sharma, Sarah (2008) 'Baring Life and Lifestyle in the Non-Place', Cultural Studies, 23:1, 129148.

Sobel, Michael E. (1981) Lifestyle and Social Structure: Concepts, Definition and Analysis. New York: Academic Press.

Ticineto Clough, Patricia \& Willse, Craig, eds. (2011) Beyond Biopolitics: Essays on the Governance of Life and Death. Durham: Duke University Press.

Tulle, Emmanuelle (2007) ‘Running to Run: Embodiment, Structure and Agency amongst Veteran Elite Runners', Sociology, 41:2, 329-346.

Van Ingen, Cathy (2004) 'Therapeutic Landscapes and the Regulated Body in the Toronto Front Runners', Sociology of Sport Journal, 21:3, 253-269.

WAA Ultra Official (2015) 'Marathon des Sables Official Shop', available at http://www.waaultra.com/en/18-marathon-des-sables-official-shop [accessed 03/05/15] 
White, Philip; Young, Kevin \& Gillett, James (1995) ‘Bodywork as Moral Imperative: some critical notes on Health and Fitness', Society and Leisure, 18:1, 159-181.

XSNRG (2007) 'Marathon des Sables - part 5', $11^{\text {th }}$ December, available at http://www.xsnrg.org/reports/?id=1074 [accessed 20/01/15].

Žižek, Slavoj (2008) Violence. London: Profile Books.

\footnotetext{
${ }^{1}$ I contacted $\mathrm{AOI}$ and Darbaroud who organize the MdS to inquire about their annual hiring practices in Ouzarzate with respect to the race. In three separate e-mail correspondences further clarifying my queries and explaining my project, they did not provide any information on their labour practices or employment contracts.
} 